\title{
Effect of Storage Conditions on Quality Characteristics of Spicy and Nonspicy Varieties of Pork Sausages
}

\author{
Subhajit Ray \\ Associate Professor, Department of Food Engineering ETechnology, Central Institute of Technology Kokrajhar, \\ Assam, India. \\ Email:subhajit@cit.ac.in Tel: +9188876215303
}

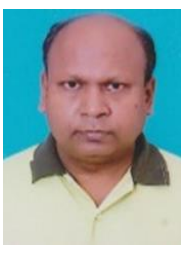

\begin{abstract}
Two different varieties of pork sausages viz. spicy and non-spicy were formulated and cooked at $700 \mathrm{C}$ for 3 minutes. Both of these two formulated varieties were packaged with low-density polyethylene and wax paper respectively and stored under refrigeration. Sensory, nutritional and microbiological characteristics of both types were analysed during different storage periods viz. 1 day, 7 days, 14 days and 21 days respectively. Evaluation of organoleptic characteristics showed greater acceptance of spicy variety in comparison to non-spicy variety. There were no significant variations in the nutritional composition of pork sausage varieties during storage. Microbiological quality of the spicy product was superior to its non-spicy counterpart. Sausages packaged in lowdensity polyethylene have the greater shelf stability than that of in waxed paper after storage periods of 14 days and 7 days respectively under refrigerated condition. Experimental results also revealed that spicy formulation has greater shelf stability than that of the nonspicy formulation.
\end{abstract}

Keywords: Pork sausage, Refrigeration, Storage stability, Low-density polyethylene, Wax paper.

Citation | Subhajit Ray (2019). Effect of Storage Conditions on Quality Characteristics of Spicy and Nonspicy Varieties of Pork Sausages. Agriculture and Food Sciences Research, 4(1): 50-56.

History:

Received: 26 January 2019

Revised: 1 March 2019

Accepted: 8 April 2019

Published: 4 June 2019

Licensed: This work is licensed under a Creative Commons

Attribution 3.0 License (cc))

Publisher: Asian Online Journal Publishing Group
Contribution/Acknowledgement: The author is grateful to the Department of Food Engineering and Technology, Central Institute of Technology Kokrajhar, Assam, Pin: 783370, India for providing necessary laboratory facilities to carry out this research work.

Funding: This study received no specific financial support.

Competing Interests: The author declares that there are no conflicts of interests regarding the publication of this paper.

Transparency: The author confirms that the manuscript is an honest, accurate, and transparent account of the study was reported; that no vital features of the study have been omitted; and that any discrepancies from the study as planned have been explained.

Ethical: This study follows all ethical practices during writing.

\section{Contents}

1. Introduction

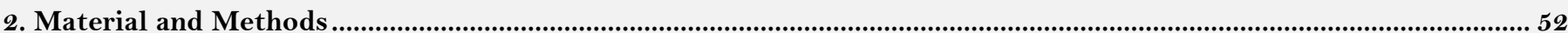

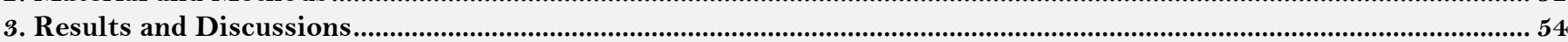

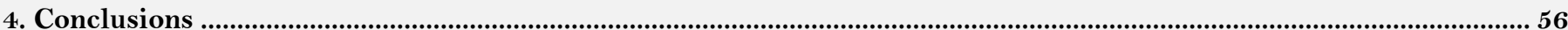

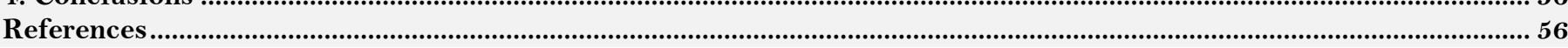




\section{Introduction}

Slaughter of animal produces a considerable amount of edible by products (head, meat, heart, tongue, tripe etc.) with high biological value and low palatability attributes [1]. Comminuted meat products offer an attractive avenue for the utilization of low-value cuts and edible offal's by replacing a certain proportion of skeletal meat to reduce their cost of production [2]. The most important component of meat is the muscle in which the myofibriller proteins form about $60 \%$ of the total muscle protein [3]. Proteins derived from raw meat and cooked pork rind; exhibit a wide range of functional properties. They are able to form networks and structures, interact with other ingredients and thus plays an important role in the texture, sensory and nutritional qualities of foods [4].Sausage is a food that is prepared from comminuted and seasoned meat and is usually into a symmetrical shape [5].Fresh comminuted meats and ingredients used as raw materials in the formulation can be modified to yield desirable organoleptic and keeping qualities of the product. In sausage preparation, raw meat batters are formed by chopping meats along with other ingredients to form a coarse dispersion of main water, fat and protein [6].In sausages and restructured meats, gel formation of myofibriller proteins is responsible for retaining and stabilizing water and fat in comminuted meats and for binding meat pieces [4]. Collagen is the main component of skin. Collagen and other connective tissue proteins play a negligible role in gel formation of sausage batter. However they are typically included in formulations for improving water binding, processing yield, juiciness and palatability or even blend cost in processed meat [7-9]. Many researchers have reported the addition of starch in various sausages in forms such as corn and potato starch, including modified starch, for evaluation of the preparation of bologna type beef sausage [10] potato flour and tapioca starch for preparation of pork sausage during refrigerated storage [1] or potato starch in low fat frankfurters [11]. Broadly speaking the basic preparation of sausage generally involves the mincing, grinding or cutting of lean meat and fat, the addition of spices, curing salts or other ingredients, followed by filling into containers [12]. Preparation of sausages predates recorded history. Sausage making developed slowly, beginning with the simple process of salting and drying meats. This was done to preserve fresh meat that could not be consumed immediately. As the human community expanded geographically, the availability of raw materials and differences in climate effected variations in manufacturing procedures. As a result, the typical flavors textures and shapes of many sausages described day today as frankfurters, Braunschweiger, pork sausage and salami were produced [5].Consumers nowadays eat sausages due to its convenience, variety, economy and nutritional value. Sausages are economical since they were commonly manufactured from the cheaper cuts of meat and from by products. In fact, sausage products no doubt resulted from the attempts of primitive man to utilize for future use the less desirable parts and by products from slaughtering. The motto of the sausage industry wills might be 'buy a pound; serve a pound' [13].Pork sausage belongs to the category of fresh sausage whereas dry and semidry sausages, cooked sausages, cooked smoked sausages, uncooked smoked sausages and cooked meat specialties were other varieties [5]. They were made from uncooked or cooked raw materials [14]. Pork sausages utilized head, neck, regular trimmings as meat sources and were a minced, cased product [15]. This type of meat products regarding emulsion type sausage was heat treated to between $75^{\circ} \mathrm{C}$ and $80^{\circ} \mathrm{C}$ to achieve desirable organoleptic properties and bacterial stability [14].They usually differ from other fresh meats in that it contains ground pork, salt and spices. Commonly but not necessarily, it has a somewhat short refrigerated shelf life because of the relatively large microbial population it contains when it was prepared from the large part of pork trimmings. They have a bright red color and were usually wrapped in oxygen permeable films such as cellophane, polyvinylchloride and polyethylene [15]. Pork sausages comprised of 30\%fat [5] soy proteins, milk proteins, starch, wheat flour and yeast as meat extenders, (3.0-3.5)\% salt [15] sucrose and dextrose as sugar [15] spices viz. ginger, onion, cinnamon, cloves, black pepper, coriander seed, etc. [5] and other ingredients as curing salt viz. sodium nitrate and nitrite or sodium nitrite alone [5] monosodiumglutamate [16] vinegar [17-19] and soysauce [20]. The majority of natural casings for sausages are obtained from the intestine of pigs, sheep and cattle. The length of gut obtained from an animal is influenced by the breed and degree of maturity [12]. Intestines intended for use as casings for sausages must be immediately processed after evisceration. First, they are emptied and well flushed. Pig, sheep and goat small intestines are scrapped thoroughly without inversion to remove the exterior (serous) and interior parts (mucous membrane), preserving the middle elastic muscle [15]. All salted natural casings should be thoroughly flushed inside with running water in the morning before use. They are then dipped into warm water to regenerate their elasticity (small intestines 10-20 minutes and large intestines 30-60 minutes) and drained for a short time before use [14]. The basic aim in cooked pork sausage manufacturing is to make a heat stable meat batter, a meat emulsion, consisting mainly of water and protein. Heat treatment transforms it from a viscous form to a rigid and elastic solid structure which can be considered as a protein gel with entrapped fat particles. If the protein gel is strong enough, the fat will not be separated during heat treatment [15]. The nutritional value of all foods including meat and meat products is being seriously considered in view of consumer interest and demand. Nutritional constituents of some sausages viz. mortadella polish style pork sausage, raw and cooked sausages, dry and cooked salami, scraple, souse, thuringer, canned vinna sausage etc. were reported according to Pearson and Tauber [13]. Proximate analysis of the main food components such as moisture, ash, fat, protein and carbohydrate and small numbers of specialized analyses based upon classical wet chemical procedures. In the age of more conventional food materials and simple food technology, such proximate and wet chemical analyses were probably sufficient for most quality control purposes [21]. The nitrogen content of meat proteins is about $16 \%$, which means the protein content of meat is 6.25 times the nitrogen content [13]. A balanced intake of fat is essential to ensure the dietary supply of essential fatty acids and the fat soluble vitamins A, D\&E [21]. Processed meats are considered to be high-fat foods. Fresh pork sausages and patties may have fat as high as $50 \%$ although the industry average is 36\% [3]. High-fat contents also lead to reduced moisture content and give less firm sausage [22]. Moisture is the most predominant component of cooked sausages, accounting for approximately $45-55 \%$ of total sausage weight but the exact amount varies depending on the amount added during preparation as well as the lean to fat ratios of the sausages [5]. The carbohydrate content of meat and meat products is usually negligible unless it is added during processing either as sugar or as carbohydrate material. Never the less, the glycogen present at the time of slaughter, although it comprises only about $1 \%$, plays a major role in determining the physical properties of meat. Studies of the mineral content of meat have been largely confirmed to calcium, phosphorus, sodium, potassium and iron. It was reported that the content of magnesium, copper and zinc were 
present in baby foods and several other processed items [13]. Microbiological quality of pork sausage greatly affected by Salmonella spp, coli forms, Staphylococcus aureus and some spore formers [20]. Salmonella spp may produce three main types of diseases i.e the enteric fevers, septicaemias and gastroenteritis [23]. Coliform bacteria may reach the bloodstream and cause sepsis. Certain coliform bacteria produce a potent enterotoxin resembling cholera toxin capable of producing acute diarrhoea, without invading intestinal epithelium. All strains of Staphylococcus aureus are potential pathogens. Under suitable conditions, strains produce a variety of toxins, the most important of which is probably $\alpha$-toxin which in the animal test is lethal, dermonecrotic, haemolytic, leucocidal and causes platelet damage [24]. Sensory characteristics by Hedonic Rating test was used to measure the consumer acceptability of pork sausage. The panelist was asked to rate the acceptability of the product on a scale, usually of nine points, ranging from like extremely to dislike extremely scale with different ranges and other experiences phrases could also be used [25]. Storage of pork sausage under refrigerated condition can enhance the shelf stability. Storage of meat products through proper packaging arrangement is an important consideration. Since the cooked sausage is perishable, the storage quality of the product can be maintained in the refrigerator for about two week [26]. Freezing is used in the food industry to extend the shelf life of the products. However, during frozen storage the formation of ice crystals can occur and lead to lower binding properties in the products [27].The packaging requirement of meat products was further influenced by the types of processing and mechanizing that may be applied to them [28]. Plastic as a packaging material encompass a whole family of natural and manmade substances [29]. The traditional package for meats was made from various types of paperboard. Papers are still extensively used, but for most applications, they are coated or combined with other materials to improve their functional qualities [28]. Wrapping materials may also be required to provide barriers to liquid water, oils and greases [30]. Waxed paper is extensively used for meat packaging. Polyethylene meets the requirement of being a tough moisture vapor proof film which retains its flexibility at temperatures as low as $51^{\circ} \mathrm{C}$. Its high porosity for oxygen was preferred for many fresh meat packaging applications [28]. Now in the present course of work two different varieties of pork sausages viz. spicy and nonspicy were developed and their storage stabilities were carried out during different periods of interval under refrigerated conditions. Sensory characteristics, nutritional characteristics and microbiological characteristics were also studied.

\section{Material and Methods}

To carry out the research pork meat purchased from Kokrajhar Market, Assam adjacent to the institution. Wheat flour, common salt, sucrose, soy sauce, ginger, onion, clove, cinnamon, pepper, coriander, low-density polyethylene, waxed paper and casing of goat were also purchased from a local market. Monosodium glutamate, sodium nitrate, sodium nitrate and acetic acid were collected from the food technology department of the institute. The methods of manufacturing of both the spicy and nonspicy varieties were represented by the following Figure 1 .

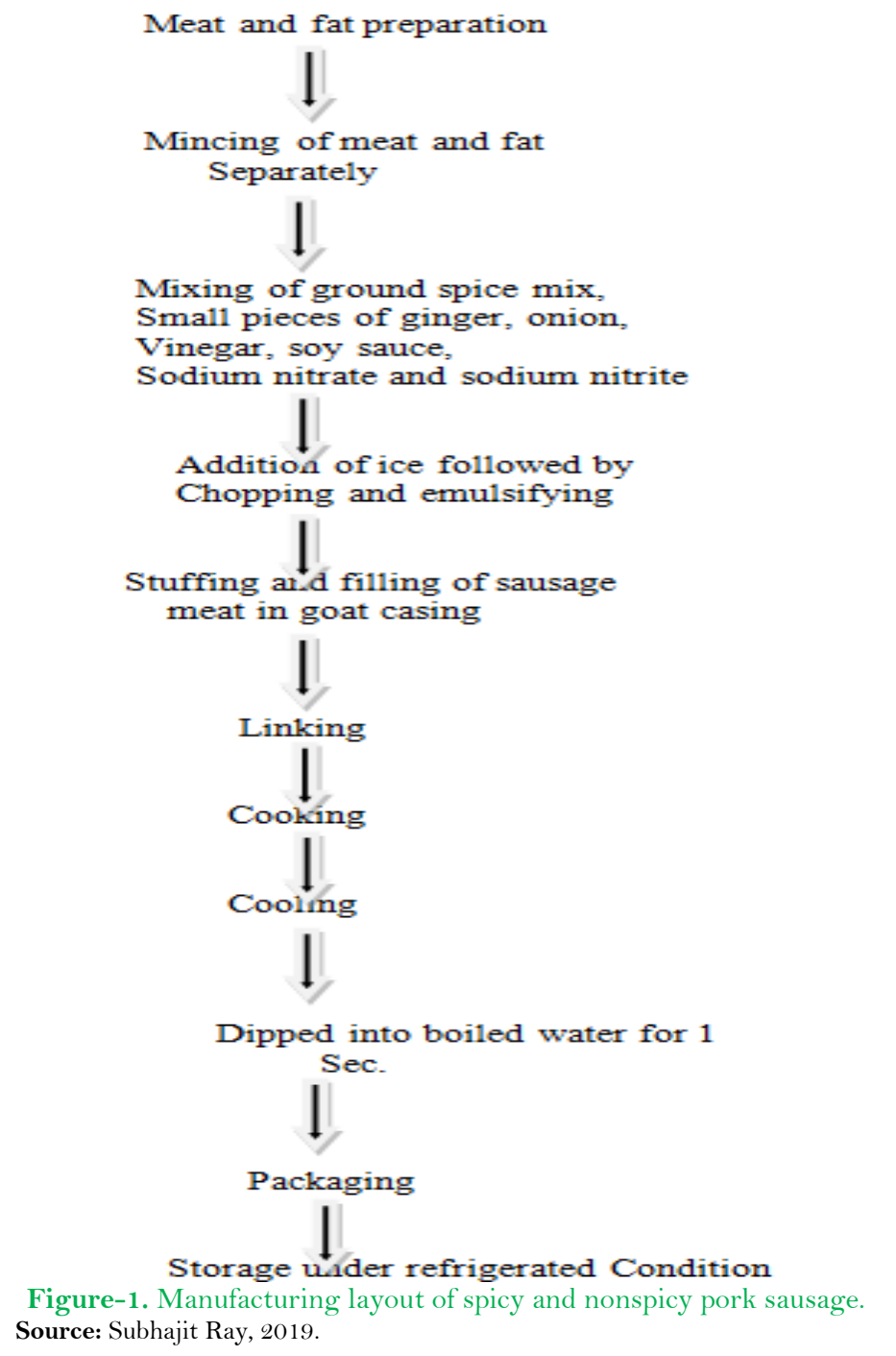

Mincing completely destroys the meat structure. Meat proteins in presence of salt, phosphate and cold water are dissolved forming a system consisting of a solution of salt-soluble proteins, muscle and connective tissue 
particles. When fatty tissue is added the fat particles will be emulsified with the salt-soluble proteins during comminution. The proteins will, therefore, be able to cover the total fat surface, surrounding each fat particle and so stabilize the emulsion. During comminution, the structural breakdown of meat and fatty tissues occurs and a new system was formed i.e minced meat suspension after addition of salt, phosphate, ice water emulsion and other additives [14]. Here the meat and fat were minced separately in a mincer through $5 \mathrm{~mm}$ diameter perforated plate. Mixer simply mixes the product to incorporate all of the ingredients [15]. Chopping was carried out by a chopper which was composed of a revolving metal bowl that contains the meat mass. A chopper was often used as a means of batching the sausage mix, the mixed batch being transferred to an emulsifier for acquiring the desired texture [13]. A table of the bench should be placed under the outlet of stuffing horn or stuffer to support the casings as it was filled and to facilitate subsequent linking [15]. In recent years final internal temperature reached in particularly all cooked sausages have gradually increased. Higher internal temperatures contribute to increase product shelf life and improved color development and stability [5].

\subsection{Screening of Sausage Formulations}

Pork emulsions were prepared by eight formulations e.g. A1, A2, A3, A4 and B1, B2, B3, B4 of non spicy and spicy varieties respectively. Quality characteristics were studied by sensory evaluation.

\subsection{Preparation of Ingredients}

The ingredients used in the preparation of meat emulsion and quantities were given in Table 1.

Table-1. Formulation of nonspicy and spicy varieties of pork sausage $(\mathrm{mg} / 100 \mathrm{gm})$

\begin{tabular}{c|c|c|c|c|c|c|c|c}
\hline I & A1 & A2 & A3 & A4 & B1 & B2 & B3 & B4 \\
\hline Pork meat & 72 & 65 & 56 & 50 & 63 & 59 & 52 & 46 \\
\hline Fat & 18.7 & 16.5 & 15 & 14 & 16.3 & 15.4 & 14.4 & 12.5 \\
\hline Binder & 4.43 & 5.8 & 7.1 & 7.2 & 5.5 & 6.00 & 7.21 & 7.92 \\
& & & & & & & & \\
\hline Salt & 1.44 & 1.44 & 1.44 & 1.44 & 1.44 & 1.44 & 1.44 & 1.44 \\
\hline Soy sauce & 1.44 & 1.44 & 1.44 & 1.44 & 1.60 & 1.60 & 1.60 & 1.60 \\
\hline Sucrose & 1.44 & 1.44 & 1.44 & 1.44 & 1.60 & 1.60 & 1.60 & 1.60 \\
\hline Ginger & 0.52 & 0.52 & 0.55 & 0.52 & 0.40 & 0.40 & 0.40 & 0.40 \\
\hline Onion & - & - & - & - & 2.42 & 2.45 & 2.45 & 2.45 \\
\hline Vinegar $_{\text {Spice mix }}$ & - & - & - & - & 0.80 & 0.80 & 0.80 & 0.80 \\
\hline Water $_{\text {NaNO }}$ & - & - & - & - & 0.20 & 0.20 & 0.20 & 0.20 \\
\hline NaNO $_{2}$ & 0.02 & 0.02 & 0.02 & 0.02 & 0,02 & 0.02 & 0.02 & 0.02 \\
\hline
\end{tabular}

Note: Legend: I - ingredients, A1, A2, A3 and A4 - non spicy variety pork sausage, B1, B2, B3 and B4 - spicy variety pork sausage.

\subsection{Sensory Evaluation Technique}

The product was fried in mustard oil and then served as coded samples for sensory evaluation. There was ten panellist including faculty members and students of the food technology department. The parameters used were color, flavor, texture, palatability and overall acceptability through nine-point hedonic rating test as suggested by Ranganna [25]. The best and appropriate two products i.e. spicy and nonspicy was selected by doing statistical analysis of sensory evaluation according to Watts, et al. [31]. These samples were used to proceed for storage stability determination under refrigeration. Both the proximate analysis and microbiological analysis were carried out.

\subsection{Nutritional Analysis}

Both the two varieties of pork sausages viz. spicy and non spicy were undergoing for nutritional analysis. The moisture content was determined by air drying method according to AOAC [32]. The crude fat content was determined according to Gerrard [12]. The moisture free sample was used to determine protein content. Carbohydrate content of the sample was determined by taking the sum starch and total sugars. The total ash of the sample was determined. For mineral contents determination, dry ashing was done and it was then used for estimation of calcium, iron and phosphorous. The titratable acidity was determined as acetic acid [26].The dried sample was used to determine the Crude fibre content according to Osborne and Voogt [21].

\subsection{Microbiological Analysis}

Microbiological analysis was carried out for both varieties of pork sausages. Total colony count in terms of total viable organisms was determined by pour plate method according to Harrigan and Mccance [33]. Presence of coli form group of organisms was enumerated by MPN technique according to Refai [34]. Detection of Salmonella sppwas done according to Varadaraj [35]. Detection of Staphylococcus aureus, a food poisoning organism was carried out according to Colee, et al. [36]. 


\section{Results and Discussions}

In this study the sensory characteristics, nutritional characteristics and microbiological quality during storage of different varieties viz.non spicy (A1, A2, A3 and A4) and spicy (B1, B2, B3 and B4) were determined.

\subsection{Sensory Characterization}

The quality of different formulations of pork sausage viz. nonspicy (A1, A2, A3 and A4) and spicy (B1, B2, B3 and B4) were evaluated according to its major sensory attributes such as color, texture, flavor, palatability and overall acceptability by nine-point hedonic rating test. The result of the experimental study was shown by the following Figure 2 and Figure 3 respectively

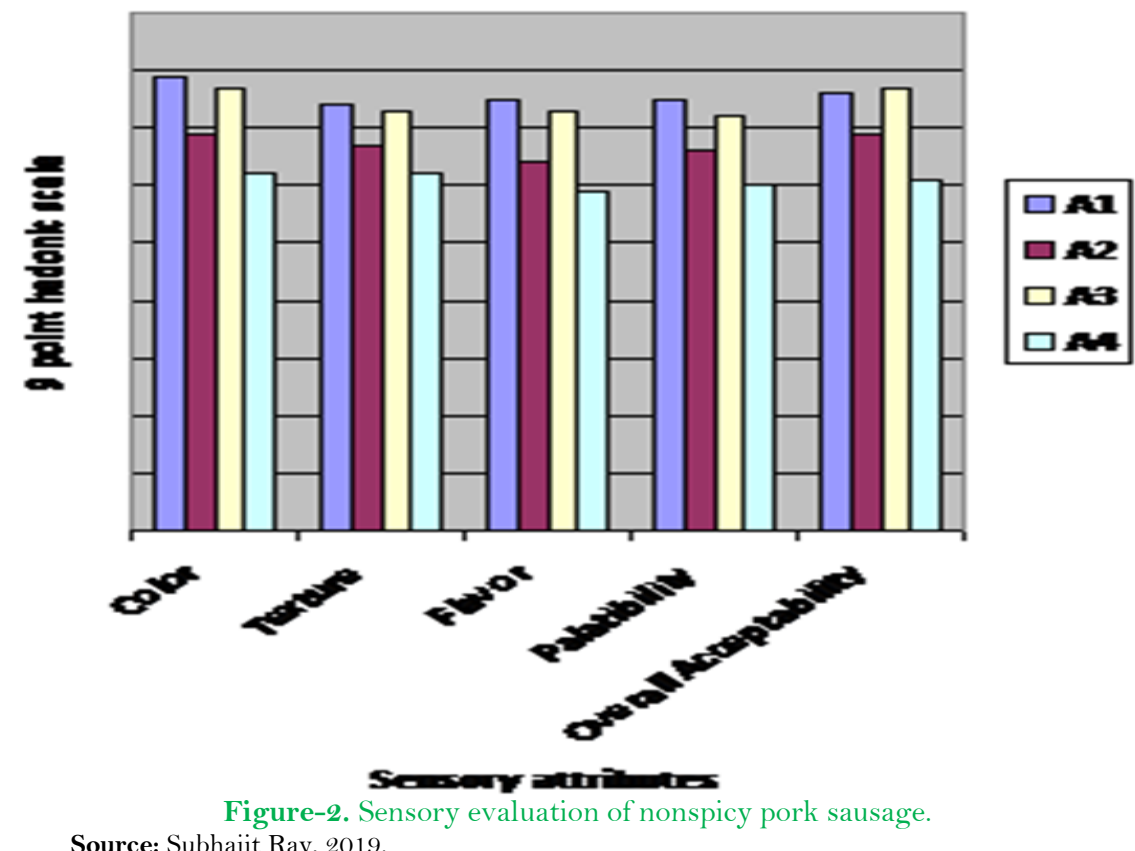

Minced and seasoned meat encased in skin and cooked or preserved, mainly to be eaten cold in slices.

Screening of sausage formulations was carried out by statistical analysis by ANOVA [31]. According to Figure 1 formulation, A1 was mostly accepted by the panelists among nonspicy formulations and this may be due to the high meat content, while it was significantly different with $\mathrm{A} 2$ and $\mathrm{A} 4$ but not different with $\mathrm{A} 3$ at $5 \%$ confidence level for the parameter overall acceptability. The formulation B2 was superior among spicy formulations according to the panellists which may be due to mild addition of

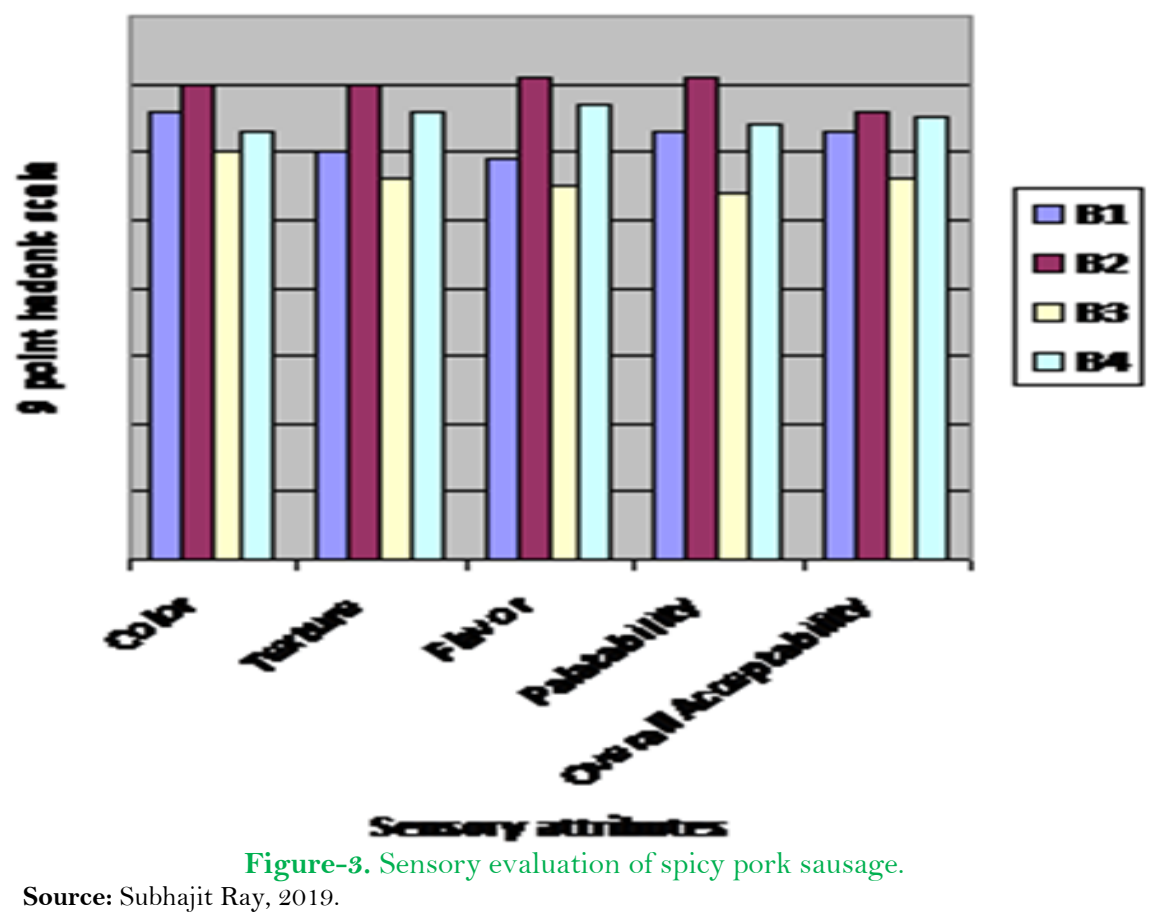

Minced and seasoned meat encased in skin and cooked or preserved, mainly to be eaten cold in slices Figure 3.

water and fine communication lead to developing in flavor and palatability. Now for the overall acceptability, the formulation B2 was significantly different with B3 but not different with B1 and B4 on the basis of overall acceptability at $5 \%$ confidence level. according to Figure 2 . So the product $\mathrm{A} 1$ and $\mathrm{B} 2$ were significantly different in color and overall acceptability while not intexture, flavor and palatability at $5 \%$ level of probability. Now the statistical analysis showed that the formulations A1 and B2 were the best among nonspicy and spicy variety respectively.

\subsection{Nutritional Characteristics during Storage}

The superior pork sausages viz. A1 of nonspicy category, B2 spicy category were stored using low-density polyethylene and waxed paper as packaging materials under refrigerated storage condition. After $1^{\text {st }}$ day and $14^{\text {th }}$ 
days of storage periods, they were analyzed for their chemical characteristics viz. moisture content, total ash, protein content, carbohydrate content, fat content, crude fibre, salt content, acidity and calcium, phosphorous and iron as minerals. The experimental results were shown in Table 2 and Table 3.

Table-2. Nutritional characteristics of pork sausage during $1^{\text {st }}$ day storage period.

\begin{tabular}{c|c|c|c|c|c|c|c|c|c|c|c}
\hline $\mathbf{C}_{1}$ & $\mathbf{P r}_{1}$ & $\mathbf{F}_{1}$ & $\mathbf{T C}_{1}$ & $\mathbf{C a}_{1}$ & $\mathbf{P}_{1}$ & $\mathbf{F e}_{1}$ & $\mathbf{S a}_{1}$ & $\mathbf{W}_{1}$ & $\mathbf{A}_{1}$ & $\mathbf{A c}_{1}$ & $\mathbf{C f}_{1}$ \\
\hline A1 in LDPE & 12.87 & 11.7 & 8.3 & 178 & 118 & 135 & 1.72 & 63.409 & 270 & 0.05 & 1.3 \\
\hline A2 in wax paper & 12.85 & 11.8 & 8.3 & 175 & 119 & 130 & 1.70 & 63.336 & 270 & 0.05 & 1.32 \\
\hline B2 in LDPE & 11.04 & 11.5 & 8.01 & 214 & 127 & 140 & 1.85 & 65.129 & 290 & 0.1 & 1.7 \\
\hline $\begin{array}{c}\text { B2in wax } \\
\text { Paper }\end{array}$ & 11.03 & 11.6 & 8.00 & 13.8 & 129 & 142 & 1.77 & 65 & 290 & 0.1 & 1.72 \\
\hline
\end{tabular}

Note: Legend: 1- $1^{\text {st }}$ day storage, $C_{1-}$ composition(gm/100gm sample), $\operatorname{Pr}_{1-}$ protein(gm), $F_{1}-$ fat $(g m), \mathrm{TC}_{1}-$ total carbohydrate $(\mathrm{gm}), \mathrm{Ca}_{1}-$ calcium(mg), $P_{1}-$ phosphorous(mg), $F_{e_{1}}-\operatorname{iron}(\mathrm{mg}), \mathrm{Sa}_{1}-\operatorname{salt}(\mathrm{gm}), \mathrm{W}_{1}-\operatorname{water}(\mathrm{gm}), \mathrm{A}_{1}-\operatorname{ash}(\mathrm{gm}), \mathrm{Ac}_{1}-\operatorname{acidity}(\%), \quad \mathrm{Cf}_{1}-\mathrm{crude}$ fat(gm),LDPE- low density polyethylene.

Table-3. Nutritional characteristics of pork sausage during $14^{\text {th }}$ day storage period.

\begin{tabular}{|c|c|c|c|c|c|c|c|c|c|c|c|}
\hline $\mathbf{C}_{14}$ & $\mathbf{P r}_{14}$ & $\mathbf{F}_{14}$ & $\mathbf{T C}_{14}$ & $\mathbf{C} \mathbf{a}_{14}$ & $\mathbf{P}_{14}$ & $\mathbf{F e}_{14}$ & $\mathbf{S a}_{14}$ & $\mathbf{W}_{14}$ & $\mathbf{A}_{14}$ & $\mathbf{A c}_{14}$ & $\mathbf{C f}_{14}$ \\
\hline A1 in LDPE & 12.8 & 11.2 & 8.4 & 180 & 119 & 130 & 1.70 & 50.0 & 272 & 0.05 & 1.3 \\
\hline A2i n wax paper & 12.2 & 11.9 & 7.9 & 174 & 121 & 135 & 1.75 & 64.217 & 273 & 0.05 & 1.33 \\
\hline B2 in LDPE & 11.3 & 11.2 & 8.1 & 220 & 125 & 148 & 1.86 & 65.033 & 294 & 0.1 & 1.72 \\
\hline $\mathrm{B} 2$ in wax Paper & 11.1 & 11.8 & 7.6 & 227 & 123 & 145 & 1.82 & 65.15 & 295 & 0.1 & 1.74 \\
\hline
\end{tabular}

acidity $(\%), \mathrm{Cf}_{14}$ - crude fat(gm), LDPE- low density polyethylene.

Table 2 and Table 3 showed that the proximate composition of the different varieties of pork sausages after $1^{\text {st }}$ day and 14 days of storage periods under refrigerated condition, a slight variation in protein, fat and moisture was observed in case of low-density polyethylene packaging for both A1 and B2 formulations. So there were no such significant variations in composition. The very low water vapor transmission rate may be responsible for this result [37]. Moreover, a decrement of protein and fat content after $1^{\text {st }}$ day and $14^{\text {th }}$ days storage period and simultaneous increment of moisture content after 14 days storage period were observed in both formulations. This was due to the fact that the water vapor transmission rate and gas transmission rate of waxed paper was significant.

\subsection{Microbiological Quality during Storage}

The microbiological analysis of the stored pork sausages after $1^{\text {st }}, 7^{\text {th }}, 14^{\text {th }}$ and $21^{\text {st }}$ days respectively of both nonspicy and spicy varieties viz. $\mathrm{A}_{1}$ and $\mathrm{B} 2$ were carried out for enumeration of the total number of microorganisms by plate count technique, Coliform count and detection of Salmonella spp, Staphylococcus aureus. The experimental results were shown in Table 4.

\begin{tabular}{c|c|c|c|c|c}
\multicolumn{2}{c}{ Table-4. Microbiological quality of pork sausage during different storage periods. } \\
\hline SV & SP & TPC & CF & S & SA \\
\hline \multirow{3}{*}{ A1 in LDPE } & 1 & 160 & - & - & - \\
\cline { 2 - 6 } & 7 & 410 & - & - & - \\
\cline { 2 - 6 } & 14 & $1.6 \times 10^{3}$ & - & - & - \\
\cline { 2 - 6 } & 21 & $4.9 \times 10^{4}$ & - & - & - \\
\hline \multirow{5}{*}{ A1in wax paper } & 1 & 210 & - & - & - \\
\cline { 2 - 6 } & 7 & $3.2 \times 10^{3}$ & 4 & - & - \\
\cline { 2 - 6 } & 14 & $6.9 \times 10^{5}$ & $>110$ & - & - \\
\hline \multirow{5}{*}{ B2 in LDPE } & 21 & $8.4 \times 10^{6}$ & $>300$ & - & - \\
\cline { 2 - 6 } & 7 & 240 & - & - & - \\
\cline { 2 - 6 } & 14 & 520 & - & - & - \\
\cline { 2 - 6 } & 21 & $4.3 \times 10^{4}$ & - & - & - \\
\hline
\end{tabular}

Note: Legend: SV- sample variety, SP- storage period (day), TPC- total plate count, CF- coliform, S- Salmonella spp, SA- Staphylococcus aureus, LDPE- low density polyethylene.

Table 4 showed that the bacteriological quality of the stored sausages. Sample B2 showed a higher initial population of bacteria in terms of total plate count than sample A1. Both A1 and B2 showed negative response during the test of coliform, Salmonella spp and Staphylococcus aureus when packed in low-density polyethylene. Both the spicy and nonspicy varieties packed in the wax paper showed high total plate count than low-density polyethylene. During different storage periods, there was an increase in the coliform count but occurrence wax only in wax paper packaged materials and at $14^{\text {th }}$ day coliform count was observed maximum in spicy variety B2. Total plate count increasing rate was low in sample B2 than in sample A1 because of antibacterial properties of spices [5] and acidic nature of the product which may control the population of microbes [16]. Both the two major food poisoning bacterias viz. Salmonella spp, Staphylococcus aureus was absent in both these two categories of sausages. Both of them were non spore formers Weiser, et al. [38] and Frobisher and Grambtree [39]. So it was evident from the result that the pork sausages packaged in the wax paper could be consumed up to one week but the same product packaged in lowdensitypolyethylene could be consumed up to two weeks when both kept under refrigerated condition. 


\section{Conclusions}

Sensory characterization revealed that among nonspicy variety and spicy variety A1 and B2 were superior to other formulations due to two important attributes viz. color and overall acceptability. The shelf life of both categories of sausages viz. A1 and B2 were greater when packaged in low-density polyethylene than packaged in wax paper under refrigerated storage condition. Moreover, it was also observed that spicy sausage viz. B2 showed greater shelf stability than nonspicy counterpart viz. A1 in context to bacteriological stability point of view. Nutritional characteristics of both these two varieties of sausages were not so prominently varied during refrigerated storage condition and as a result, showed its health beneficial importance.

\section{References}

[1] W. S. Ruban, A. Kalaikannan, and V. Apparao, "Physico-chemical characteristics of pork sausage during refrigerated storage," Veterinary World, vol. 2, pp. 95-97, 2009.

[2] M. Salahuddin, N. Kondaiah, and A. Anjaneyulu, "Effect of maida, potato and textured soya as binders on the quality of chicken and mutton kababs," Journal of Food Science and Technology, vol. 28, pp. 301-303, 1991.

Y. L. Xiong, Structure-function relationships of muscle proteins. In S. Damodaran \& A Paraf (Eds.), Food protein and their applications. New York: Marcel Dekker, 2005.

[4] W. Visessanguan, W. Benjakul, S. Panya, C. Kittikun, and A. Assavanig, "Meat Science," vol. 69, pp. 355-362, 1997.

[5] W. E. Kramlich, Sausage products, the science of meat and meat products, 2nd ed. Sanfransisco: J.F.W.H. Freeman and Company, 1971.

[6] R. Prabpree and R. Pongsawatmanit, "Effect of tapioca starch concentration on quality and freeze-thaw stability of fish sausage," Kasetsart Journal of Natural Sciences, vol. 45, pp. 314-324, 2011.

[7] S. Eilert, D. Blackmer, R. Mandigo, and C. Calkins, "Meat batters manufactured with modified beef connective tissue," Journal of Food Science, vol. 58, pp. 691-696, 1993.Available at: https://doi.org/10.1111/j.1365-2621.1993.tbo9336.x.

[8] A. Jobbling, "New applications of collagenous proteins in meat products," Journal of the Science of Food and Agriculture, vol. 35 , pp. 1264-1265, 1984.

[9] W. Osburn, R. Mandigo, and K. Eskridge, "Pork skin connective tissue gel utilization in reduced-fat bologna," Journal of Food Science, vol. 62, pp. 1176-1182, 1997.Available at: https://doi.org/10.1111/j.1365-2621.1997.tb12239.x.

[10] N. Aktaş and H. Genccelep, "Effect of starch type and its modifications on physicochemical properties of bologna-type sausage produced with sheep tail fat," Meat Science, vol. 74, pp. 404-408, 2006.Available at: https://doi.org/10.1016/j.meatsci.2006.04.012.

[11] M. Luruena-Martınez, A. Vivar-Quintana, and I. Revilla, "Effect of locust bean/xanthan gum addition and replacement of pork fat with olive oil on the quality characteristics of low-fat frankfurters," Meat Science, vol. 68, pp. 383-389, 2004.Available at: https://doi.org/10.1016/j.meatsci.2004.04.005.

[12] F. Gerrard, Sausage and small goods production, 6th ed. London: Northwood Publication Ltd, 1976.

[14] Food and Agriculture Organization FAO, Animal production and health paper, guidelines for slaughtering, meat curing and further processing Rome: Food and Agriculture Organization of the United Nations, 1991.

[15] S. Small Scale Processing of Pork, Technology series, Technical memorandum No.9. Geneva: International Labor Office, 1985.

[16] N. N. Potter and J. H. Hotchkiss, Food science, 3rd ed. India: CBS Publisher and Distributors, 1987.

$[17] \quad$ D. N. W. and J. N. Desrosier, The technology of food preservation, 4th ed. India: CBS Published and Distributors, 1987.

[18] S. Giridharilal, G. S. Siddappa, and G. L. Tandon, Preservation of fruits and vegetables, publication and information division. India: Indian Council of Agricultural Research, 1986.

[19] R. A. Lawrie, Meat science, 5th ed. Oxford: Pergamon Press, 1991.

[20] G. Reed, Prescott and Dunn's industrial microbiology. India: CBS Publishers and Distributors, 1987.

[21] D. R. Osborne and P. Voogt, The analysis of nutrients in foods. London: Academic Press, 1978.

[22] A. Stiebing and W. Rodel, Influence of relative humidity on the ripening of dry sausage. Frankfurt: Fleisch Wirtschaff International Deutscher Fachverlag, 1989.

[23] E. Jawetz, J. L. M. Melnick, and A. Adelburg, Review of medical microbiology. Los Altos, California: Lange Medical Publications, 1974 .

[24] R. E. Buchanan and N. E. Gibbons, Bergey's manual of determinative bacteriology, American society of microbiology,Bergey D.H. and Breed Robert $S$, 7 th ed. USA: Baltimore,Williams \& Wilkins Co, 1957.

[25] S. Ranganna, Handbook of analysis and quality control for fruits and vegetable products, 2nd ed. New Delhi: Tata McGraw-Hill Publishing Company Limited, 1986.

[26] Q. L. Dong, L. Y. Guo, J. L. Yang, H. Wang, and Y. Y. Chen, "The effect of sodium nitrite on the textural properties of cooked sausage during cold storage," Journal of Texture Studies, vol. 38, pp. 537-554, 2007.Available at: https://doi.org/10.1111/j.17454603.2007.00112.x.

[27] D. Dexter, J. Sofos, and G. Schmidt, "Quality characteristics of turkey bologna formulated with carrageenan, starch, milk and soy protein," Journal of Muscle Foods, vol. 4, pp. 207-223, 1993.Available at: https://doi.org/10.1111/j.1745-4573.1993.tbo0503.x.

[28] J. M. Ramsbottom, Packaging. The science of meat and meat products, 2nd ed. Sanfransisco: J.F.W.H. Freeman and Company, 1971. R. C. Griffin and S. Sacharow, Principles of packaging development. Westport Connecticut: The AVI Publishing Company Inc, 1978. R. P. Goddard, Wrapping and packaging papers, Ed. By Paine, F.A. The packaging media. London: Blackie and Sons Ltd, 1977. B. M. Watts, G. L. Ylimaki, and L. G. Elias, Basic sensory methods for food evaluation. Canada: The International Development Research Centre, 1989.

[32] AOAC, Official methods of analysis of AOAC international - 20th Edition, 2016, Editor:Dr. George W. Latimer, Jr, 20th ed. vol. 45. USA: Published by AOAC International, 2012.

[33] W. F. Harrigan and M. E. Mccance, Laboratory methods in food and dairy microbiology. New York: Academic Press Inc, 1976.

[34] M. K. Refai, Manuals of food quality control, microbiological analysis. Rome: FAO.The United Nations, 1979

[35] M. Varadaraj, "Methods for detection and enumeration of foodborne bacterial pathogens: A critical evaluation," Journal of Food Science and Technology, vol. 30, pp. 1-13, 1993.

[36] J. G. Colee, J. P. Duguid, and B. P. Marmion, Practical medical microbiology, 8th ed. Baltimore, USA: The Williams and Wilkins Company, 1989.

[37] Export, Export packaging note No.16, International trade centre. Switzerland: UNCTAD/ GATT, 2011.

[38] H. H. Weiser, G. J. Mountney, and W. A. Gould, Practical food microbiology and technology, 2nd ed. Westport, Connecticut: The AVI Publishing Company Inc, 1971.

[39] H. Frobisher and G. Grambtree, Fundamentals of microbiology, 9th ed. Japan: Toppan Company limited, 1974. 